\title{
PENGARUH STRATEGI PEMBELAJARAN KOOPERATIF TIPE JIGSAW DAN GAYA BERPIKIR TERHADAP HASIL BELAJAR MATEMATIKA
}

\author{
Japar Siddik Rambe, Abdul Hamid K., Mukhtar \\ Sekolah Menengah Pertama Negeri 2 Bilah Hilir Kabupaten Labuhanbatu \\ japarsiddikrambe@gmail.com
}

\begin{abstract}
Abstrak: Tujuan penelitian ini adalah untuk mengetahui: (1) hasil belajar matematika yang diajar dengan strategi pembelajaran Kooperatif tipe jigsaw dan strategi pembelajaran ekspositori; (2) hasil belajar matematika siswa yang mempunyai Gaya berpikir sekuensial abstrak dan yang mempunyai Gaya berpikir konkrit dalam mempengaruhi hasil belajar; dan (3) Interaksi antara strategi pembelajaran dan Gaya berpikir dalam mempengaruhi hasil belajar matematika. Hasil penelitian menunjukkan bahwa: (1) Terdapat perbedaan rata-rata hasil belajar matematika antara siswa yang dibelajarkan dengan strategi pembelajaran Kooperatif Tipe Jigsaw dengan siswa yang dibelajarkan dengan strategi pembelajaran Ekspositori. Rata-rata hasil belajar Matematika siswa yang dibelajarkan dengan Strategi Kooperatif Tipe Jigsaw lebih tinggi dari hasil belajar Matematika siswa yang dibelajarkan dengan Strategi Ekspositori. (2) Rata-rata hasil belajar Matematika siswa yang memiliki Gaya berpikir Sekuensial Konkrit lebih tinggi daripada hasil belajar Matematika siswa yang memiliki Gaya berpikir Sekuensial Abstrak, dan (3).Terdapat interaksi antara penggunaan Strategi pembelajaran dan Gaya berpikir dalam mempengaruhi hasil belajar Matematika siswa.
\end{abstract}

Kata Kunci: strategi pembelajaran kooperatif tipe jigsaw, gaya berpikir, matematika

Abstract: The purpose of this study is to find out: (1) mathematics learning outcomes taught by the Jigsaw Cooperative learning strategy and expository learning strategies; (2) mathematics learning outcomes of students who have abstract sequential thinking styles and who have concrete thinking styles in influencing learning outcomes; and (3) The interaction between learning strategies and thinking styles in influencing mathematics learning outcomes. The results showed that: (1) There was a difference in the average learning outcomes of mathematics between students who were taught with the Jigsaw Cooperative learning strategy with students who were taught with Expository learning strategies. The average student learning outcomes in Mathematics that are taught with the Jigsaw Cooperative Strategy are higher than the learning outcomes in Mathematics students who are taught with the Expository Strategy. (2) The average Mathematics learning outcomes of students who have Concrete Sequential Thinking styles are higher than the Mathematics learning outcomes of students who have Abstract Sequential Thinking Styles, and (3). There is an interaction between the use of learning strategies and Thinking Styles in influencing student learning outcomes in Mathematics.

Keywords: Jigsaw type cooperative learning strategies, thinking style, mathematics

\section{PENDAHULUAN}

Paradigma sistem pendidikan nasional yang selama ini menjadi acuan penyelenggaraan pendidikan di Indonesia perlu dikaji dan disempurnakan. Paradigma sistem pendidikan nasional harus mencakup faktor proses dan konteks di samping input dan output pendidikan bahkan dalam hal pendidikan input justru tidak dipermasalahkan. Faktor-faktor proses dan konteks itulah yang malah menentukan output pendidikan. Karena itu masalah-masalah semacam kurikuler, kualitas guru, metode pengajaran yang efektif dan menyenangkan serta manajemen menjadi sangat penting dalam proses sistem tersebut yang menjadi meningkat dan mampu mengembangkan keterampilan dan kepribadiannya.

Mulyono (1999) menyatakan bahwa komponen-komponen yang mempengaruhi hasil belajar seorang siswa meliputi (1) stimuli belajar, (2) metode belajar, (3) individual siswa. Hal ini senada yang diungkapkan oleh Van Dallen (1973) menyatakan komponen- 
komponen yang mempengaruhi hasil belajar seorang siswa meliputi : (1) guru, (2) kurikulum, (3) siswa, (4) media, (5) metode mengajar, dan (6) lingkungan. Untuk tercapainya tujuan pembelajaran yang maksimal, maka antara komponen-komponen tersebut harus saling mendukung satu dengan lainnya.

Strategi pembelajaran yang dikembangkan sudah barang tentu didasarkan atas kondisi materi matematika. Dikarenakan matematika mengandung prinsip - prinsip dan kaidah, serta setiap bagian (topik/subtopik) memiliki struktur tersendiri, dengan demikian penggunaan strategi Kooperatif tipe jigsaw dapat diterapkan.

Degeng (1990) mengemukakan bahwa apabila karakteristik siswa dilibatkan dalam penentuan strategi pembelajaran, maka karakteristik siswalah yang lebih berperan untuk menentukan strategi pembelajaran mana yang sebaiknya digunakan dalam kegiatan belajar.

\section{Hakikat Hasil Belajar Matematika}

Skinner (1969) menyebutkan belajar adalah suatu perubahan dalam kemungkinan atau peluang terjadinya respon yang dapat dilihat sebagai suatu perilaku dimana pada saat seseorang belajar maka responnya akan lebih baik, dan sebaliknya pada saat seosorang tidak belajar maka responnya akan menurun. Selanjutnya menurut skinner dalam belajar akan ditemukan hal-hal sebagai berikut : (1) kesempatan terjadinya peristiwa-peristiwa belajar; (2) respon orang yang belajar; (3) konsekuensi yang bersifat menggunakan respon tersebut, baik konsekuensi sebagai hadiah maupun teguran atau hukuman.

Belajar juga merupakan suatu proses perubahan tingkah laku sebagai suatu hasil interaksi dengan lingkungannya dalam memenuhi kebutuhannya dengan ciri-ciri : (1) perubahan terjadi secara sadar; (2) perubahan dalam belajar terjadi bersifat kontinyu dan fungsional; (3) perubahan dalam belajar bersifat positif dan aktif artinya perubahan itu senantiasa bertambah dan tertuju untuk memperoleh sesuatu yang lebih baik dari sebelumnya; (4) perubahan dalam belajar bukan bersifat sementara, tetapi bersifat permanen; (5) perubahan dalam belajar bertujuan dan terarah; (6) perubahan dalam belajar mencakup seluruh aspek tingkah laku (Slameto, 1995). Senada dengan pendapat tersebut, Fudyartanto (2002) menjelaskan bahwa ciri-ciri perubahan tingkah laku dalam belajar sebagai berikut (a) belajar adalah perubahan dalam diri seseorang yang dinyatakan dalam kecakapan suatu sikap; (b) belajar adalah penguasaan pola-pola perilaku baru; (c) belajar adalah penguasaan kecakapan, sikap, dan pengertian dalam belajar yang sesungguhnya. Dari pengertian tersebut dapat dipahami dengan belajar manusia memperoleh perubahan tingkah laku dalam bentuk suatu kecakapan ataupun kepandaian.

Belajar merupakan tindakan perilaku siswa yang kompleks, yang membawa perubahan dalam diri seseorang. Dalam belajar terdapat hal-hal yang paling pokok untuk dipahami yaitu: 1) belajar itu membawa perubahan dalam arti behaviorial changes, aktual, maupun potensial; 2) perubahan tersebut pada pokoknya adalah didapatkannya kecakapan baru; 3) perubahan itu terjadi karena usaha-usaha atau dengan sengaja (Suryabrata, 2008).

Dari uraian tentang pengertian belajar, dapat dikemukakan bahwa melalui belajar manusia mengalami perubahan-perubahan dalam kebiasaan, kecakapan yang berkaitan pada aspek pengetahuan, sikap, dan keterampilan. Dengan demikian, belajar merupakan aktivitas mental yang membawa perubahan relatif permanen dan diperoleh melalui pengalaman. Pendapat tersebut dikemukakan Hamalik (2003) yang mengemukakan bahwa belajar merupakan perubahan tingkah laku yang relatif mantap berkat latihan dan pengalaman. Definisi belajar yang dikemukakan oleh Hamalik mengandung pengertian bahwa dalam belajar harus dilakukan dengan sengaja, direncanakan sebelumnya dengan struktur tertentu dan membentuk tingkah laku yang baru. Sejalan dengan pendapat tersebut, Daradjat (2002) menyatakan bahwa belajar adalah suatu bentuk perubahan dalam diri seseorang yang dinyatakan dengan cara-cara bertingkah laku yang baru berkat pengalaman dan latihan. Dalam hal ini belajar senantiasa merupakan kegiatan yang berlangsung di dalam suatu proses dan terarah kepada pencapaian suatu tujuan tertentu dan menghasilkan perubahan tingkah laku. Perubahan tingkah laku tersebut dilakukan secara sadar dan timbul akibat praktik, pengalaman, latihan, dan bukan secara kebetulan.

Sedangkan mengenai pengertian
Matematika Erman 
mengemukakan bahwa Matematika merupakan bagian matematika yang diberikan untuk dipelajari oleh siswa sekolah (formal). Menurut Soedjadi (1995) Matematika adalah bagian atau unsur dari matematika yang dipilih antara lain dengan pertimbangan atau berorentasi pada pendidikan. Dengan demikian dapat disimpulkan bahwa Matematika adalah matematika yang telah dipilah-pilah dan disesuaikan dengan tahap perkembangan intelektual siswa, serta digunakan sebagai salah satu sarana untuk mengembangkan kemampuan berpikir bagi para siswa.

$$
\text { Uhar Suharsaputra }
$$

menyimpulkan banyak guru yang menguasai materi suatu subyek dengan baik tetapi tidak dapat melaksanakan kegiatan pembelajaran dengan baik. Hal itu terjadi menurut Uhar, karena kegiatan belajar mengajar tidak didasarkan pada suatu Strategi pembelajaran tertentu sehingga mengakibatkan hasil belajar siswa menjadi rendah. Diduga kuat, rendahnya hasil belajar siswa pada mata pelajaran matematika juga terkait erat dengan persoalan metode ataupun Strategi pembelajaran.

\section{Hakekat Pembelajaran Kooperatif tipe jigsaw}

Kooperatif berasal dari kata Kooperatif yang artinya mengerjakan sesuatu secara bersama-sama dengan saling membantu satu sama lainnya sebagai satu kelompok atau satu tim. Kooperatif atau pembelajaran Kooperatif merupakan strategi belajar dengan sejumlah siswa sebagai anggota kelompok kecil yang tingkat kemampuannya berbeda. Menurut Slavin (1985), Kooperatif adalah suatu Strategi pembelajaran dimana siswa belajar dan bekerja dalam kelompok-kelompok kecil secara kolaboratif yang anggotanya 4-6 orang dengan struktur kelompok heterogen. Sedangkan Johnson (dalam Hasan, 1984) mengemukakan bahwa Kooperatif mengandung arti bekerja bersama dalam mencapai tujuan bersama.

Anita Lie (2000) menyebutkan Kooperatif dengan istilah pembelajaran gotong royong, yaitu sistem pembelajaran yang memberi kesempatan kepada peserta didik untuk bekerjasama dengan siswa lain dalam tugas-tugas yang terstruktur. Pembelajaran kelompok adalah rangkaian kegiatan belajar yang dilakukan oleh siswa dalam kelompokkelompok tertentu untuk mencapai tujuan pembelajaran yang telah dirumuskan. Ada empat unsur penting dalam strategi pembelajaran Kooperatif, yaitu : 1) adanya peserta dalam kelompok; 2) adanya aturan kelompok 3) adanya upaya belajar setiap anggota kelompok; dan 4) adanya tujuan yang harus dicapai. Peserta adalah siswa yang melakukan proses pembelajaran dalam setiap kelompok belajar. Pengelompokan siswa ditetapkan berdasarkan beberapa pendekatan, seperti pengelompokan yang didasarkan atas minat dan bakat siswa, pengelompokan yang didasarkan atas latar belakang kemampuan. Aturan kelompok adalah segala sesuatu yang menjadi kesepakatan semua pihak yang terlibat, baik siswa sebagai peserta didik maupun siswa sebagai anggota kelompok, misalnya pembagian tugas setiap anggota kelompok, waktu dan tempat pelaksanaan, dan lain sebagainya. Upaya belajar adalah segala aktivitas siswa untuk meningkatkan kemampuannya yang telah dimiliki maupun meningkatkan kemampuan baru, baik kemampuan dalam aspek pengetahuan, sikap, dan keterampilan. Aspek tujuan dimaksudkan untuk memberikan arah perencanaan, pelaksanaan, dan evaluasi. Melalui tujuan diharapkan setiap anggota kelompok dapat memahami sasaran setiap kegiatan belajar.

Prosedur pembelajaran Kooperatif tipe jigsaw pada prinsipnya terdiri atas empat tahapan, yaitu : 1) penjelasan materi; 2) belajar dalam kelompok; 3) penilaian; dan 4) pengakuan tim. Tahap penjelasan materi merupakan suatu proses penyampaian pokokpokok materi pelajaran sebelum siswa belajar dalam kelompok. Tujuannya adalah agar siswa dapat memahami pokok materi pelajaran yang akan berlangsung. Kauchak dan Eggen dalam Azizah (1998) berpendapat Kooperatif merupakan strategi pembelajaran yang melibatkan siswa untuk bekerja secara kolaboratif dalam mencapai tujuan. Djahiri $\mathrm{K}$ (2004) menyebutkan Kooperatif sebagai pembelajaran kelompok Kooperatif yang menuntut diterapkannya pendekatan belajar yang siswa sentries, humanistik, dan demokratis yang disesuaikan dengan kemampuan siswa dan lingkungan belajarnya. Beberapa ciri dari Kooperatif adalah; a) setiap anggota memiliki peran, b) terjadi hubungan interaksi langsung diantara siswa, c) setiap anggota kelompok bertanggung jawab atas belajarnya dan juga teman-teman sekelompoknya, d) guru membantu mengembangkan keterampilanketerampilan interpersonal kelompok, dan e) guru hanya berinteraksi dengan kelompok saat 
diperlukan. Sistem pengajaran Kooperatif dapat didefinisikan sebagai sistem kerja/ belajar kelompok yang terstruktur. Yang termasuk di dalam struktur ini adalah lima unsur pokok (Johnson \& Johnson, 1993), yaitu saling ketergantungan positif, tanggung jawab individual, interaksi personal, keahlian bekerja sama, dan proses kelompok. Falsafah yang mendasari pembelajaran Kooperatif (pembelajaran gotong royong) dalam pendidikan adalah "homo homini socius" yang menekankan bahwa manusia adalah makhluk sosial. Menurut Anita Lie dalam bukunya "Kooperatif", bahwa strategi pembelajaran Kooperatif tidak sama dengan sekadar belajar kelompok, tetapi ada unsur-unsur dasar yang membedakannya dengan pembagian kelompok yang dilakukan asal-asalan.

Jigsaw merupakan salah satu strategi pembelajaran kelompok (Kooperatif). Pembelajaran Kooperatif tipe Jigsaw adalah suatu tipe pembelajaran Kooperatif yang terdiri dari beberapa anggota dalam satu kelompok yang bertanggung jawab atas penguasaan bagian materi belajar dan mampu mengajarkan materi tersebut kepada anggota lain dalam kelompoknya (Arends, 1997). Strategi pembelajaran Kooperatif tipe Jigsaw merupakan strategi pembelajaran Kooperatif dimana siswa belajar dalam kelompok kecil yang terdiri dari $4-6$ orang secara heterogen dan bekerja sama saling ketergantungan yang positif dan bertanggung jawab atas ketuntasan bagian materi pelajaran yang harus dipelajari dan menyampaikan materi tersebut kepada anggota kelompok yang lain. Jigsaw didesain untuk meningkatkan rasa tanggung jawab siswa terhadap pembelajarannya sendiri dan juga pembelajaran orang lain. Siswa tidak hanya mempelajari materi yang diberikan, tetapi mereka juga harus siap memberikan dan mengajarkan materi tersebut pada anggota kelompoknya yang lain. Dengan demikian, "siswa saling tergantung satu dengan yang lain dan harus bekerja sama secara Kooperatif untuk mempelajari materi yang ditugaskan" (Lie, A., 1994).

\section{Hakekat pembelajaran ekspositori}

Istilah ekspositori berasal dari konsep eksposisi yang berarti memberi penjelasan. Dalam konteks pembelajaran, eksposisi merupakan strategi yang dilakukan guru untuk mengatakan atau menjelaskan fakta-fakta, gagasan-gagasan dan informasi-informasi penting lainnya kepada para pebelajar. Komunikasi yang digunakan dalam kegiatan proses pembelajaran masih menggunakan komunikasi satu arah dimana guru bertindak sebagai penyampai informasi serta siswa sebagai responden yang akan mengikuti penjelasan yang disampaikan oleh guru tersebut atau dengan istilah lainnya guru merupakan tokoh yang harus ditiru dalam segala hal menyangkut kegiatan pembelajaran yang telah dilaksanakan. Materi pelajaran seakan-akan sudah jadi. Oleh karena strategi ekspositori lebih menekankan kepada proses bertutur, maka sering juga dinamakan istilah strategi "chalk and talk". Sejalan dengan hal tersebut Sanjaya (2006) menyatakan bahwa Strategi pembelajaran ekspositori adalah strategi pembelajaran yang menekankan kepada proses penyampaian materi secara verbal dari seorang guru kepada sekelompok siswa dengan maksud agar siswa dapat menguasai materi pelajaran secara optimal. Selanjutnya Roy Killen (1998) menamakan strategi pembelajaran ekspositori dengan istilah pembelajaran langsung (direct instruction) karena di dalam strategi ini materi pelajaran disampaikan secara langsung oleh guru sementara siswa tidak dituntut untuk menemukan materi itu sendiri. Karakteristik strategi pembelajaran ekspositori antara lain : 1). dilakukan dengan cara penyampaian materi pembelajaran secara verbal artinya bertutur secara lisan yang merupakan alat utama dalam melakukan strategi pembelajaran. 2). materi yang disampaikan adalah materi pembelajaran yang sudah jadi, seperti data atau fakta, konsepkonsep tertentu yang harus dihafal sehingga tidak menuntut siswa untuk berpikir ulang. 3). Tujuan utama pembelajaran adalah penguasaan materi sendiri artinya setelah proses pembelajaran berakhir siswa diharapkan dapat memahami yang benar yaitu mengingat kembali materi yang telah diuraikan.

\section{Hakekat Gaya berpikir}

Setiap siswa memiliki perbedaan kemampuan dalam hal penguasan pembelajaran dan hal ini perlu diperhatikan dalam pelaksanaan kegiatan pembelajaran. Dengan adanya perbedaan tersebut perlu dicari solusi yang tepat untuk mengatasi hal tersebut serta untuk memahami perbedaan yang ada pada diri siswa. Ellis (1979) mengemukakan bahwa pendekatan yang lazim digunakan adalah dengan mengelompokkan orang berdasarkan tipenya, mengembangkan skala untuk 
mengukur kualitas manusia yakni ciri manusia yang konsisten dari situasi ke situasi berikutnya. Definisi yang paling umum dari berfikir adalah berkembangnya ide dan konsep (Bochenski, dalam Suriasumantri, 1983) di dalam diri seseorang. Perkembangan ide dan konsep ini berlangsung melalui proses penjalinan hubungan antara bagian-bagian informasi yang tersimpan di dalam diri seseorang yang berupa pengertian-pengertian. Dari gambaran ini dapat dilihat bahwa berfikir pada dasarnya adalah proses psikologis dengan tahapan-tahapan berikut : (1) pembentukan pengertian, (2) penjalinan pengertian, dan (3) penarikan kesimpulan.

Kemampuan berpikir pada manusia alamiah sifatnya. Manusia yang lahir dalam keadaan normal akan dengan sendirinya memiliki kemampuan ini dengan tingkat yang relatif berbeda. Jika demikian, yang perlu diupayakan dalam proses pembelajaran adalah mengembangkan kemampuan ini. Tellier dan Dryeden (2003) mengatakan bahwa Gaya berpikir adalah cara yang konsisten yang dilakukan oleh individu dalam mencari informasi, cara mengingat serta memikirkan cara penyelesaian suatu persoalan.

Rumusan masalah yang ingin diperhatikan dalam penelitian ini adalah: (1) Apakah hasil belajar matematika siswa yang diajar dengan strategi pembelajaran Kooperatif akan memperoleh hasil belajar yang berbeda dengan siswa yang diajar dengan strategi pembelajaran ekspositori ?; (2) Apakah hasil belajar siswa yang memiliki Gaya berpikir sekuensial konkrit menunjukkan perbedaan dengan hasil belajar siswa yang memiliki Gaya berpikir sekuensial abstrak?; dan (3) Apakah terdapat interaksi antara strategi pembelajaran Kooperatif dan Gaya berpikir dalam mempengaruhi hasil belajar matematika?

\section{METODE}

Penelitian ini dilaksanakan di SMP Negeri 2 Bilah Hilir Kabupaten Labuhanbatu,
Jalan Lintas Negeri Lama - Tanjung Sarang Elang Kecamatan Bilah Hilir Kabupaten Labuhanbatu. Yang menjadi alasan penulis memilih sekolah ini sebagai tempat penelitian adalah karena sekolah ini belum pernah dilakukan sebelumnya penelitian yang berkaitan dengan strategi pembelajaran dalam kegiatan proses pembelajaran. Penelitian ini dilaksanakan dengan menggunakan metode kuasi eksperimen. Metode ini dipilih karena penelitian dilakukan pada kelas yang sudah terbentuk sebelumnya tanpa ada manipulasi situasi kelas maupun jadwal pelajaran yang digunakan.

Dalam penelitian ini terdapat dua variabel bebas dan satu variabel terikat yaitu yang menjadi variabel bebas adalah strategi pembelajaran Kooperatif tipe jigsaw dan strategi pembelajaran ekspositori, sedangkan yang menjadi variabel terikat adalah hasil belajar matematika. Pembagian kelas dibagi menjadi dua kelompok yaitu satu kelompok sebagai kelas perlakuan dan satu kelompok lagi sebagai kelas kontrol. Pada kelas perlakuan digunakan strategi pembelajaran Kooperatif tipe jigsaw sedangkan kelas kontrol digunakan strategi pembelajaran ekspositori. Populasi penelitian ini adalah seluruh siswa kelas VIII (delapan) SMP Negeri 2 Bilah Hilir Kabupaten Labuhanbatu yang terdiri dari 5 kelas berjumlah 198 orang. Berdasarkan populasi tersebut dilakukan teknik pengambilan sampel secara acak (simple random sampling). Untuk menetapkan jumlah sampel ada dua persyaratan yang harus dipenuhi yaitu sampel harus refresentatif (mewakili) dan besarnya harus memadai.

Penelitian ini digunakan Desain faktorial 2 x 2, Melalui Disain ini akan dibandingkan pengaruh antara strategi pembelajaran Kooperatif tipe jigsaw dan strategi pembelajaran ekspositori terhadap hasil belajar matematika ditinjau dari gaya berpikir.

Tabel 1. Desain Penelitian Faktorial 2x2

\begin{tabular}{|c|c|c|}
\hline $\begin{array}{l}\text { Strategi Pembelajaran (A) } \\
\text { Berfikir Gaya (B) }\end{array}$ & $\begin{array}{l}\text { Kooperatif tipe jigsaw } \\
\qquad \mathrm{A}_{1}\end{array}$ & $\begin{array}{l}\text { Ekspositori } \\
\mathrm{A}_{2}\end{array}$ \\
\hline Sekuensial Konkrit $\left(\mathrm{B}_{1}\right)$ & $\mathrm{A}_{1} \mathrm{~B}_{1}$ & $\mathrm{~A}_{2} \mathrm{~B}_{1}$ \\
\hline Sekuensial Abstrak $\left(\mathrm{B}_{2}\right)$ & $\mathrm{A}_{1} \mathrm{~B} 2$ & $\mathrm{~A}_{2} \mathrm{~B}_{2}$ \\
\hline \multicolumn{3}{|c|}{$\begin{array}{lcc}\text { Keterangan : } & \mathrm{A}_{1} & \text { : Strategi pembelajaran kooperatif tipe } \\
\mathrm{A} \quad: \text { Strategi pembelajaran } & & \end{array}$} \\
\hline B : Gaya berpikir & $\mathrm{A}_{2} \quad: \mathrm{St}$ & pembelajaran \\
\hline
\end{tabular}


$\mathrm{B}_{1} \quad$ : Gaya berpikir sekuensial konkrit

$\mathrm{B}_{2} \quad$ : Gaya berpikir sekuensial abstrak

$\mathrm{A}_{1} \mathrm{~B}_{1}$ : Hasil belajar yang dikenai pengaruh interaksi strategi pembelajaran kooperatif tipe jigsaw dan gaya berpikir sekuensial konkrit.

$\mathrm{A}_{1} \mathrm{~B}_{2}$ : Hasil belajar yang dikenai pengaruh interaksi strategi pembelajaran kooperatif tipe jigsaw dan gaya berpikir sekuensial abstrak.

$\mathrm{A}_{2} \mathrm{~B}_{1}$ : Hasil belajar yang dikenai pengaruh interaksi strategi pembelajaran ekspositori dan gaya berpikir sekuensial konkrit.

$\mathrm{A}_{2} \mathrm{~B}_{1}$ : Hasil belajar yang dikenai pengaruh interaksi strategi pembelajaran ekspositori dan gaya berpikir sekuensial abstrak.

Teknik analisis data yang digunakan dalam penelitian ini adalah teknik statistik deskriftif dan interensial. Teknik statistik deskriftif digunakan untuk mendeskripsikan data, antara lain : nilai rata-rata (mean), median, standar deviasi (sd) dan kecenderungan data. Teknik statistik inferensial digunakan untuk menguji hipotesis penelitian dengan teknik analisis varians (ANAVA) dua jalur ( disain faktorial $2 \times 2$ ) dengan taraf signifikan $\alpha=$ 0,05 .

Sebelum anava dua jalur dilakukan, terlebih dahulu ditentukan uji persyaratan analisis, yaitu persyaratan normalitas dan homogenitas. Uji persyaratan normalitas menggunakan uji Liliefors, dan uji persyaratan homogenitas menggunakan uji barlett dan uji Fisher. Setelah melakukan pengujian persyaratan analisis, selanjutnya dilakukan pengujian Anava 2 jalur. Jika ternyata Anava 2 jalur signifikan maka diadakan uji lanjut menggunakan uji scheffe sebab sampel setiap sel tidak sama.

Untuk keperluan pengujian hipotesis, maka perlu dirumuskan hipotesis statistik sebagai berikut :

1. Ho: $\mu \mathrm{A}_{1} \leq \mu \mathrm{A}_{2}$

$\mathrm{Ha}: \mu \mathrm{A}_{1}>\mu \mathrm{A}_{2}$

2. Ho: $\mu \mathrm{B}_{1} \leq \mu \mathrm{B}_{2}$

$\mathrm{Ha}: \mu \mathrm{B}_{1}>\mu \mathrm{B}_{2}$

3. Ho: interaksi $\mathrm{A}><\mathrm{B}=0$

$\mathrm{Ha}$ : interaksi $\mathrm{A}><\mathrm{B} \neq 0$

Keterangan

$\mu \mathrm{A}_{1} \quad$ : rata-rata hasil belajar matematika yang diajarkan dengan strategi pembelajaran jigsaw

$\mu \mathrm{A}_{2}$ : rata-rata hasil belajar matematika yang diajarkan dengan strategi pembelajaran ekspositori

$\mu \mathrm{B}_{1} \quad$ : rata-rata hasil belajar matematika memiliki Gaya berpikir sekuensial konkrit

$\mu \mathrm{B}_{2} \quad$ : rata-rata hasil belajar matematika memiliki Gaya berpikir sekuensial abstrak

A : Strategi Pembelajaran

B : Gaya Berpikir

\section{HASIL DAN PEMBAHASAN}

Hasil

Pengujian hipotesis dilakukan menggunakan teknik analisis varians (ANAVA). Untuk keperluan analisis varians, data yang diperlukan dapat dilihat pada Tabel 2 .

Tabel 2. Data Hasil Belajar Matematika Siswa

\begin{tabular}{|c|c|c|c|c|c|c|c|c|c|}
\hline \multirow{2}{*}{$\begin{array}{c}\text { Gaya } \\
\text { berpikir } \\
\text { (B) }\end{array}$} & \multicolumn{6}{|c|}{$\begin{array}{c}\text { Strategi Pembelajaran (A) } \\
\end{array}$} & \\
\hline & \multicolumn{3}{|c|}{$\begin{array}{c}\text { Strategi Kooperatif } \\
\text { Tipe Jigsaw }\left(\mathbf{A}_{1}\right)\end{array}$} & \multicolumn{3}{|c|}{$\begin{array}{c}\text { Strategi Ekspositori } \\
\left(\mathbf{A}_{2}\right)\end{array}$} & & & \\
\hline $\begin{array}{l}\text { GP } \\
\text { Sekuensial } \\
\text { Konkrit } \\
\left(\mathrm{B}_{1}\right)\end{array}$ & $\begin{array}{l}\mathrm{nA}_{1} \mathrm{~B}_{1} \\
\Sigma \mathrm{X} \\
\Sigma \mathrm{X}^{2} \\
X\end{array}$ & $\begin{array}{l}= \\
= \\
= \\
=\end{array}$ & $\begin{array}{l}22 \\
690 \\
21762 \\
31,36 \\
\end{array}$ & $\begin{array}{l}\mathrm{nA}_{2} \mathrm{~B}_{1} \\
\Sigma \mathrm{X} \\
\Sigma \mathrm{X}^{2} \\
X\end{array}$ & $\begin{array}{l}= \\
= \\
=\end{array}$ & $\begin{array}{l}19 \\
523 \\
14683 \\
27,52 \\
\end{array}$ & $\begin{array}{l}\mathrm{n}_{\mathrm{t}} \\
\Sigma \mathrm{X} \\
\Sigma \mathrm{X}^{2} \\
X_{\mathrm{t}}\end{array}$ & $\begin{array}{l}= \\
= \\
= \\
=\end{array}$ & $\begin{array}{l}41 \\
1213 \\
36445 \\
29,44 \\
\end{array}$ \\
\hline $\begin{array}{l}\text { GP } \\
\text { Sekuensial } \\
\text { Abstrak } \\
\left(\mathrm{B}_{2}\right)\end{array}$ & $\begin{array}{l}\mathrm{nA}_{1} \mathrm{~B}_{2} \\
\Sigma \mathrm{X} \\
\Sigma \mathrm{X}^{2} \\
X \\
\end{array}$ & $\begin{array}{l}= \\
= \\
= \\
=\end{array}$ & $\begin{array}{l}18 \\
494 \\
13786 \\
27,44 \\
\end{array}$ & $\begin{array}{l}\mathrm{nA}_{2} \mathrm{~B}_{2} \\
\Sigma \mathrm{X} \\
\Sigma \mathrm{X}^{2} \\
X \\
\end{array}$ & $\begin{array}{l}= \\
= \\
=\end{array}$ & $\begin{array}{l}21 \\
580 \\
16190 \\
27,61 \\
\end{array}$ & $\begin{array}{l}\mathrm{n}_{\mathrm{t}} \\
\Sigma \mathrm{X} \\
\Sigma \mathrm{X}^{2} \\
X_{\mathrm{t}}\end{array}$ & $\begin{array}{l}= \\
= \\
= \\
=\end{array}$ & $\begin{array}{l}39 \\
1074 \\
29976 \\
27,52 \\
\end{array}$ \\
\hline Total & $\begin{array}{l}\mathrm{n}_{\mathrm{t}} \\
\Sigma \mathrm{X} \\
\Sigma \mathrm{X}^{2} \\
X_{\mathrm{t}}\end{array}$ & $\begin{array}{l}= \\
= \\
= \\
=\end{array}$ & $\begin{array}{l}40 \\
1184 \\
35548 \\
29,4 \\
\end{array}$ & $\begin{array}{l}\mathrm{n}_{\mathrm{t}} \\
\Sigma \mathrm{X} \\
\Sigma \mathrm{X}^{2} \\
X_{\mathrm{t}}\end{array}$ & $\begin{array}{l}= \\
=\end{array}$ & $\begin{array}{l}40 \\
1103 \\
30873 \\
27,56\end{array}$ & $\begin{array}{l}\mathrm{n}_{\mathrm{t}} \\
\Sigma \mathrm{X} \\
\Sigma \mathrm{X}^{2} \\
X_{\mathrm{t}}\end{array}$ & $\begin{array}{l}= \\
= \\
= \\
=\end{array}$ & $\begin{array}{l}80 \\
2287 \\
66421 \\
28,48 \\
\end{array}$ \\
\hline
\end{tabular}


Hasil perhitungan ANAVA seperti yang ditunjukkan dalam Tabel 3, yaitu rangkuman analisis faktorial $2 \times 2$.

Tabel 3. Rangkuman Analisis Faktorial 2x2

\begin{tabular}{|l|l|c|l|l|l|l|}
\hline Sumber Varians & JK & Dk & RJK & $\mathbf{F}_{\text {hitung }}$ & $\mathbf{F}_{\text {tabel }}$ & Kesimpulan \\
\hline Strategi & 82,01 & 1 & 82,01 & 7,72 & & Signifikan \\
Pembelajaran & & & & & 3,96 & Signifikan \\
Gaya Berpikir & 83,74 & 1 & 83,74 & 7,88 & & Signifikan \\
Interaksi & 875,64 & 1 & 875,64 & 82,45 & & \\
\hline Antar Kelompok & 234,15 & 3 & 78,05 & & & \\
Dalam Kelompok & 807,24 & 76 & 10,62 & & & \\
\hline Total & $\mathbf{1 0 4 1 , 3 9}$ & & & & & \\
\hline
\end{tabular}

Berdasarkan rangkuman di atas maka akan dirinci pengujian hipotesis sebagai berikut :

1. Perbedaan Pengaruh Strategi Pembelajaran

Kooperatif tipe Jigsaw dengan Strategi

Pembelajaran Ekspositori terhadap hasil belajar matematika

Pengujian hipotesis pertama yang menyatakan hasil belajar Matematika siswa yang dibelajarkan dengan Strategi Pembelajaran Kooperatif Tipe Jigsaw lebih tinggi daripada hasil belajar siswa yang diajarkan dengan Strategi Pembelajaran Ekspositori, Hipotesis statistiknya adalah :

Ho: $\mu \mathrm{A}_{1} \leq \mu \mathrm{A}_{2} \quad$ Ha: $\mu \mathrm{A}_{1}>\mu \mathrm{A}_{2}$

Pernyataan hipotesis tersebut adalah :

Ho $=$ Tidak terdapat perbedaan hasil belajar Matematika antara siswa yang dibelajarkan dengan menggunakan Strategi Pembelajaran Kooperatif Tipe Jigsaw dengan siswa yang dibelajarkan dengan menggunakan Strategi Pembelajaran Ekspositori.

$\mathrm{Ha}=$ siswa yang dibelajarkan dengan menggunakan Strategi Pembelajaran Kooperatif Tipe Jigsaw memperoleh hasil belajar Matematika lebih tinggi daripada siswa yang dibelajarkan dengan Strategi Pembelajaran Ekspositori.

Berdasarkan perhitungan ANAVA faktorial $2 \times 2$ diperoleh $\mathrm{F}_{\text {hitung }}=7,72$ sedangkan nilai $\mathrm{F}_{\text {tabel }}=3,96$ untuk $\mathrm{dk}(1,76)$ dan taraf nyata $\alpha=0,05$. Ternyata nilai $F_{\text {hitung }}=7,72>F_{\text {tabel }}$ sehingga pengujian hipotesis menolak Ho. Dengan demikian dapat ditarik kesimpulan bahwa hasil belajar Matematika siswa yang dibelajarkan dengan Strategi Pembelajaran Kooperatif Tipe Jigsaw lebih tinggi dibandingkan dengan Strategi Pembelajaran Ekspositori dapat diterima dan terbukti secara empirik. Hal ini juga terlihat dari rata-rata hasil belajar Matematika yang dibelajarkan dengan Strategi Pembelajaran Kooperatif Tipe Jigsaw $(X=29,4)$ lebih tinggi dari hasil belajar Matematika yang dibelajarkan dengan Strategi Pembelajaran Ekspositori ( $X=27,56$ ).

2. Perbedaan Hasil belajar matematika antara Siswa yang memiliki Gaya berpikir Sekuensial Konkrit dengan Siswa yang memiliki Gaya berpikir Sekuensial Abstrak

Pengujian hasil kedua yang menyatakan : Hasil belajar Matematika siswa yang memiliki Gaya berpikir Sekuensial Konkrit, lebih tinggi daripada hasil belajar siswa yang diajarkan dengan Gaya berpikir Sekuensial Abstrak, Hipotesis statistiknya adalah:

Ho : $\mu \mathrm{B}_{1} \leq \mu \mathrm{B}_{2}$

$\mathrm{Ha}: \mu \mathrm{B}_{1}>\mu \mathrm{B}_{2}$

Pernyataan hipotesis tersebut adalah :

Ho $=$ Tidak terdapat perbedaan hasil belajar Matematika antara siswa yang memiliki Gaya berpikir Sekuensial Konkrit dengan siswa yang memiliki Gaya berpikir Sekuensial Abstrak

$\mathrm{Ha}=$ Siswa yang memiliki Gaya berpikir Sekuensial Konkrit memperoleh hasil belajar Matematika lebih tinggi daripada siswa yang memiliki Gaya berpikir yang Sekuensial Abstrak

Berdasarkan perhitungan ANAVA faktorial 2x2 diperoleh $\mathrm{F}_{\text {hitung }}=7,88$ sedangkan nilai $\mathrm{F}_{\text {tabel }}=$ 3,96 untuk dk $(1,76)$ dan taraf nyata $\alpha=0,05$. Ternyata nilai $F_{\text {hitung }}=7,88>F_{\text {tabel }}$ sehingga pengujian hipotesis menolak Ho. Dengan demikian dapat ditarik kesimpulan bahwa hasil belajar Matematika siswa yang memiliki Gaya berpikir Sekuensial Konkrit lebih tinggi dibanding siswa yang memiliki Gaya berpikir Sekuensial Abstrak dapat diterima dan terbukti 
secara empirik. Hal ini juga terlihat dari ratarata hasil belajar Matematika yang memiliki Gaya berpikir Sekuensial Konkrit $\quad(X=29,44)$ lebih tinggi dari hasil belajar Matematika yang memiliki Gaya berpikir Sekuensial Abstrak ( $X$ $=27,52$ ).

Interaksi antara Strategi Pembelajaran dengan Gaya berpikir dalam mempengaruhi Hasil belajar matematika Siswa

Pengujian hipotesis yang ketiga yaitu: terdapat interaksi antara strategi Pembelajaran dan Gaya berpikir dalam meningkatkan hasil belajar Matematika.

Ho : $\mathrm{A}><\mathrm{B}=0 \mathrm{Ha}: \mathrm{A}><\mathrm{B} \neq 0$

Pernyataan hipotesis tersebut adalah :

$\mathrm{Ha}=$ Tidak terdapat interaksi antara Strategi Pembelajaran dan Gaya berpikir terhadap hasil belajar Matematika siswa.
Ho $=$ Terdapat interaksi antara Strategi pembelajaran dan Gaya berpikir terhadap hasil belajar Matematika siswa.

Berdasarkan perhitungan ANAVA faktorial $2 \times 2$ diperoleh $F_{\text {hitung }}=82,45$ sedangkan nilai $\mathrm{F}_{\text {tabel }}=3,96$ untuk dk $(1,76)$ dan taraf nyata $\alpha=0,05$. Ternyata nilai $F_{\text {hitung }}=82,45>F_{\text {tabel }}$ sehingga pengujian hipotesis menolak Ho. Dengan demikian dapat ditarik kesimpulan bahwa terdapat interaksi antara Strategi Pembelajaran dan Gaya berpikir dalam meningkatkan hasil belajar Matematika siswa dapat diterima dan terbukti secara empirik.

Untuk mengetahui interaksi antara Strategi Pembelajaran dan Gaya berpikir terhadap hasil belajar Matematika, maka dilakukan uji lanjut dengan Uji Scheffe.

Tabel 4. Rangkuman Uji Scheffe

\begin{tabular}{|c|c|c|c|}
\hline \multicolumn{2}{|c|}{ Hipotesis Statistik } & $F_{\text {hitung }}$ & $F_{\text {tabel }}(3,76) \alpha=0,05$ \\
\hline Ho $: \mu \mathrm{A}_{1} \mathrm{~B}_{1}=\mu \mathrm{A}_{2} \mathrm{~B}_{1}$ & $\mathrm{Ha}: \mu \mathrm{A}_{1} \mathrm{~B}_{1}>\mu \mathrm{A}_{2} \mathrm{~B}_{1}$ & 3,686 & 2,72 \\
\hline Ho $: \mu \mathrm{A}_{1} \mathrm{~B}_{1}=\mu \mathrm{A}_{1} \mathrm{~B}_{2}$ & $\mathrm{Ha}: \mu \mathrm{A}_{1} \mathrm{~B}_{1}>\mu \mathrm{A}_{1} \mathrm{~B}_{2}$ & 3,654 & 2,72 \\
\hline Ho $: \mu \mathrm{A}_{1} \mathrm{~B}_{1}=\mu \mathrm{A}_{2} \mathrm{~B}_{2}$ & $\mathrm{Ha}: \mu \mathrm{A}_{1} \mathrm{~B}_{1}>\mu \mathrm{A}_{2} \mathrm{~B}_{2}$ & 3,794 & 2,72 \\
\hline Ho $: \mu \mathrm{A}_{1} \mathrm{~B}_{2}=\mu \mathrm{A}_{2} \mathrm{~B}_{1}$ & $\mathrm{Ha}: \mu \mathrm{A}_{1} \mathrm{~B}_{2}<\mu \mathrm{A}_{2} \mathrm{~B}_{1}$ & 0,070 & 2,72 \\
\hline Ho $: \mu \mathrm{A}_{1} \mathrm{~B}_{2}=\mu \mathrm{A}_{2} \mathrm{~B}_{2}$ & $\mathrm{Ha}: \mu \mathrm{A}_{1} \mathrm{~B}_{2}<\mu \mathrm{A}_{2} \mathrm{~B}_{2}$ & 0,155 & 2,72 \\
\hline Ho $: \mu \mathrm{A}_{2} \mathrm{~B}_{1}=\mu \mathrm{A}_{2} \mathrm{~B}_{2}$ & $\mathrm{Ha}: \mu \mathrm{A}_{2} \mathrm{~B}_{1}<\mu \mathrm{A}_{2} \mathrm{~B}_{2}$ & 0,085 & 2,72 \\
\hline
\end{tabular}

Hasil pengujian lanjut di atas, menunjukkan adanya interaksi antara Strategi Pembelajaran dan Gaya berpikir terhadap hasil belajar Matematika siswa SMP Negeri 2 Bilah Hilir Kabupaten Labuhanbatu di kelas VIII semester genap.

interaksi Strategi Pembelajaran dan Gaya berpikir dapat ditunjukkan seperti pada Gambar 4.9 berikut ini :

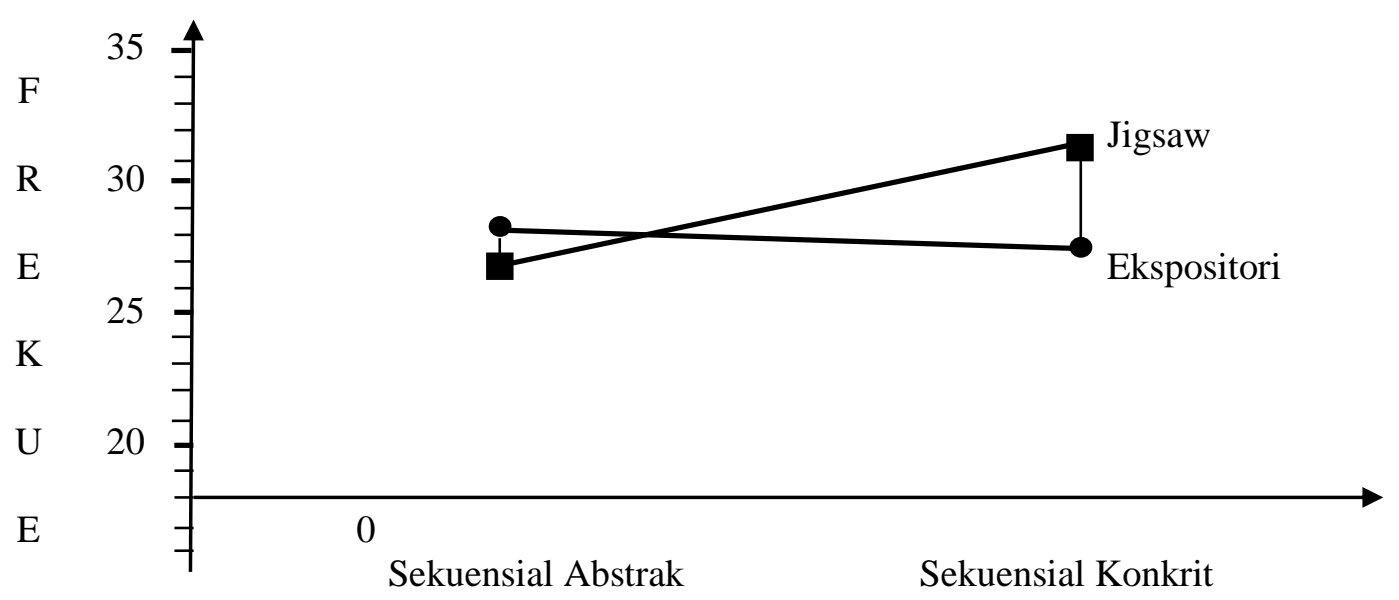

Gambar 1. Interaksi Antara Strategi Pembelajaran dan Gaya Berpikir

Berdasarkan hasil pengujian hipotesis ketiga yang menyatakan adanya interaksi antara Strategi Pembelajaran dan Gaya berpikir maka perlu dilakukan uji perbedaan rata-rata antara dua proporsi. Gambar 1 menunjukkan pengaruh dan interaksi dari Strategi Pembelajaran dan Gaya berpikir terhadap hasil belajar Matematika siswa yang diperoleh siswa, ratarata hasil belajar Matematika yang dibelajarkan dengan Strategi Pembelajaran Kooperatif Tipe 
Jigsaw lebih tinggi dibandingkan dengan Strategi Pembelajaran Ekspositori. Penelitian ini juga membuktikan faktor Gaya berpikir sebagai salah satu karakteristik siswa perlu diperhatikan karena terbukti bahwa Gaya berpikir berpengaruh terhadap hasil belajar Matematika.

\section{Pembahasan}

Perbedaan Hasil Belajar matematika Antara Siswa Yang Diajarkan Dengan Menggunakan Strategi Pembelajaran Kooperatif Tipe Jigsaw Dan Siswa Yang Diajarkan Dengan Menggunakan Strategi Pembelajaran Ekspositori.

Dari hasil pengolahan data yang dilakukan terdapat perbedaaan hasil belajar matematika antara peserta didik yang diajarkan menggunakan strategi pembelajaran kooperatif tipe jigsaw dengan strategi ekspositori, hal ini ditunjukkan dari nilai rata-rata hasil belajar Matematika siswa yang diajar dengan menggunakan strategi pembelajaran Kooperatif Tipe Jigsaw lebih tinggi dibandingkan siswa yang diajar dengan menggunakan strategi pembelajaran ekspositori. Kenyataan ini membuktikan bahwa penggunaan strategi pembelajaran Kooperatif Tipe Jigsaw lebih baik dalam meningkatkan pengetahuan peserta didik dalam pembelajaran Matematika.

Slavin (1995) mengemukakan dua alasan mengapa strategi pembelajaran kooperatif dianjurkan oleh para ahli pendidikan untuk digunakan. Pertama, beberapa hasil penelitian membuktikan bahwa penggunaan pembelajaran kooperatif dapat meningkatkan prestasi belajar siswa sekaligus dapat meningkatkan kemampuan hubungan social, menumbuhkan sikap menerima kekurangan diri dan orang lain, serta dapat meningkatkan harga diri. Kedua, pembelajaran kooperatif dapat merealisasikan kebutuhan siswa dalam berpikir, memecahkan masalah, dan mengintegrasikan pengetahuan dan keterampilan. Ada empat unsur penting dalam kegiatan pembelajaran Kooperatif Tipe Jigsaw di kelas, yaitu sebagai berikut : (1) adanya peserta dalam kelompok; (2) adanya aturan kelompok; (3) adanya upaya belajar setiap anggota kelompok; dan (4) adanya tujuan yang harus dicapai.

Sanjaya (2008: 178) menyatakan strategi pembelajaran ekspositori adalah strategi pembelajaran yang menekankan kepada proses penyampaian materi secara verbal dari seorang guru kepada sekelompok siswa dengan maksud agar siswa dapat menguasai materi pelajaran secara optimal. Strategi pembelajaran ekspositori merupakan bentuk dari pendekatan berorientasi kepada guru (teacher centered approach). Dikatakan demikian karena dalam strategi ini guru memegang peran yang sangat dominan, melalui strategi ini guru menyampaikan materi pelajaran yang disampaikan itu dapat dikuasai siswa dengan baik. Fokus utama I pembelajaran dengan kuliah merupakan ciri khas dari strategi pembelajaran ekspositori.

Dari hasil pengamatan dan diskusi peneliti bersama dengan guru dalam pengkajian strategi pembelajaran pada kelas Kooperatif Tipe Jigsaw dan ekspositori, untuk kelas perlakuan strategi pembelajaran Kooperatif Tipe Jigsaw untuk tahapan perumusan masalah untuk dipecahkan peserta didik, guru hanya memberi masalah atau soal-soal yang berbeda untuk dicari penyelesaiannya oleh siswa sedangkan pada kelas yang diberi perlakuan strategi pembelajaran ekspositori guru lebih banyak menyelesaikan soal-soal yang disajikan dalam contoh. Hal ini dibuktikan dengan lamanya waktu penyajian materi pelajaran pada kelas ekspositori dibandingkan dengan waktu penyajian materi pada kelas Kooperatif Tipe Jigsaw. Pada kelas Kooperatif Tipe Jigsaw siswa menemukan sendiri pengetahuan dari masalah yang diberikan guru sehingga pengetahuan tersebut akan lebih bermakna. Hal ini menyebabkan menjadi penyebab tingginya hasil belajar matematika pada kelas Kooperatif Tipe Jigsaw.

Pada tahapan penetapan jawaban sementara atau pengajuan hipotesis, dari hasil pengamatan dan diskusi peneliti beserta guru yang dilibatkan tampak bahwa siswa pada kelas Kooperatif Tipe Jigsaw menemukan langsung jawaban sementara dan pembuktian atas tugastugas yang diberikan guru untuk diselesaikan. Sedangkan pada kelas ekspositori, siswa cenderung dan pasif dan malu-malu untuk bertanya. Hal ini menjadi penyebab lebih tingginya hasil belajar Matematika pada kelas Kooperatif Tipe Jigsaw.

Pada tahapan peserta didik mencari informasi, data dan fakta yang diperlukan untuk menjawab atau memecahkan masalah dan menguji hipotesis. Dari hasil pengamatan dan diskusi peneliti beserta guru yang dilibatkan tampak bahwa siswa pada kelas Kooperatif Tipe Jigsaw cenderung lebih aktif mencari informasi bagaimana cara atau langkah untuk 
menyelesaikan soal-soal yang diberikan guru dan mereka lebih berani bertanya kepada guru jika kesulitan dalam memecahkan masalah matematika. Sedangkan pada kelas ekspositori, tampak siswa lebih cenderung pasif, siswa lebih dominan dibimbing oleh guru tentang langkahlangkah bagaimana menyelesaikan soal matematika dan jika ada kesulitan hanya beberapa orang saja yang berani bertanya dan selebihnya kurang memberikan respon. Hal ini menjadi penyebab lebih tingginya hasil belajar Matematika pada kelas Kooperatif Tipe Jigsaw.

Pada tahapan menarik kesimpulan dari jawaban. Dari hasil pengamatan dan diskusi peneliti beserta guru yang dilibatkan tampak bahwa siswa pada kelas Kooperatif Tipe Jigsaw cenderung lebih aktif dalam memahami materi pelajaran yang disajikan dalam bentuk contoh soal dan mereka dapat lebih mudah memahami bagaimana menarik kesimpulan dari materi secara keseluruhan. Sedangkan pada kelas ekspositori siswa lebih cenderung diam, mendengar dan mencatat materi pelajaran yang diberikan oleh guru dan kesimpulan dari materi pelajaran juga atas kesimpulan yang diperoleh atas arahan guru. Peneliti menyimpulkan hal ini sebagai penyebab lebih tingginya hasil belajar Matematika pada kelas yang diberi perlakuan strategi pembelajaran Kooperatif Tipe Jigsaw dibandingkan dengan strategi ekspositori.

Pada tahapan aplikasi kesimpulan atau generalisasi dalam situasi baru. Dari hasil pengamatan dan diskusi peneliti beserta guru yang dilibatkan tampak bahwa siswa pada kelas Kooperatif Tipe Jigsaw dapat mengaplikasikan kesimpulan dari materi yang dipelajari lebih tinggi dari siswa pada kelas ekspositori dan ini terlihat dari mereka dapat menyelesaikan soalsoal dalam tingkat kesukaran yang berbeda. Dari dua strategi pembelajaran matematika yaitu strategi pembelajaran Kooperatif Tipe Jigsaw dan strategi pembelajaran ekspositori tampak jelas perbedaan cara menyelesaikan masalah atau soal matematika oleh siswa, pada strategi Kooperatif Tipe Jigsaw siswa dapat menyelesaiakan masalah atau tugas secara mandiri walaupun belum dapat dikatakan jawaban tersebut benar, namun mereka berupaya untuk menemukan jawaban dari permasalahan yang ada, berbeda dengan siswa yang diajarkan dengan strategi ekspositori yang hanya dapat menyelesaikan masalah atau soal matematika setelah adanya contoh yang diberikan oleh guru.
Peneliti menyimpulkan pada kelas yang diberi strategi pembelajaran Kooperatif Tipe Jigsaw presentase yang dilakukan kelompok Kooperatif Tipe Jigsaw terhadap hasil temuan siswa di dalam kelompok adalah kesimpulan terhadap hasil diskusi temuan siswa, sedangkan pada kelas ekspositori kesimpulan lebih cenderung dilakukan oleh guru dengan hanya memberi penekanan pada tujuan pelajaran yang akan dicapai setelah selesai melaksanakan pembelajaran. Hal ini menyebabkan lebih tingginya hasil belajar matematika pada kelas Kooperatif Tipe Jigsaw.

Perbedaan Hasil Belajar Matematika Antara Siswa Yang Memiliki Gaya berpikir Sekuensial Konkrit Dan Siswa Yang Memiliki Gaya berpikir Sekuensial Abstrak

Hasil penelitian menunjukkan bahwa rata-rata hasil belajar Matematika siswa yang memiliki Gaya berpikir Sekuensial Konkrit lebih tinggi dari pada hasil belajar Matematika siswa yang memiliki Gaya berpikir Sekuensial Abstrak. Hal ini mengindikasikan bahwa siswa yang memiliki Gaya berpikir Sekuensial Konkrit lebih mampu memahami pelajaran Matematika dibandingkan dengan siswa yang memiliki Gaya berpikir Sekuensial Abstrak.

Proses kognisi, atau proses berpikir, berkaitan dengan penjelasan mengenai apa yang terjadi dalam otak siswa selama memperoleh pengetahuan baru, yaitu bagaimana pengetahuan baru tersebut diperoleh, diatur, disimpan dalam memori, dan digunakan lebih lanjut dalam pembelajaran dan pemecahan masalah.

Dalam hal gaya berpikir, anak yang memiliki Gaya berpikir Sekuensial Konkrit, proses pengembangan kognitif atau berpikir akan berkembang apabila diberi kesempatan untuk mengasahnya dengan memberi kebabasan belajar, berkreasi, berpikir dan memecahkan masalah dari berbagai cara, sebab dengan begitu anak dapat mewujudkan dirinya sebagai seseorang yang memiliki kemampuan untuk melihat bermacam-macam kemungkinan penyelesaian terhadap suatu masalah, memberikan kepuasan kepada siswa dan memungkinkan meningkatkan kualitas hidupnya. Sebaliknya, bagi anak yang memiliki Gaya berpikir Sekuensial Abstrak, peran guru sebagai pengarah dan fasilitator sangat dibutuhkan untuk mengembangkan pola pikirnya dalam mengerjakan tugas-tugas yang hendak diteliti. Selanjutnya kebiasaan 
memecahkan masalah dan orientasi perhatian perlu perhatian di tumbuh kembangkan termasuk dalam proses belajar di sekolah.

Dari data yang diperoleh menunjukkan bahwa hasil belajar siswa yang memiliki Gaya berpikir Sekuensial Konkrit lebih tinggi daripada hasil belajar siswa yang memiliki Gaya berpikir Sekuensial Abstrak pada kelas Kooperatif Tipe Jigsaw, hal ini disebabkan oleh karena karakteristik siswa yang memiliki Gaya berpikir Sekuensial Konkrit lebih cenderung menonjolkan indra fisik, yaitu indra penglihatan, peraba, pendengaran, perasa, dan penciuman. Mereka memperhatikan dan mengingat realitas dengan mudah dan mengingat fakta, informasi, rumus-rumus, dan aturan-aturan khusus dengan mudah sedangkan pada kelas yang diajarkan dengan strategi pembelajaran ekspositori menunjukkan bahwa hasil belajar siswa yang memiliki Gaya berpikir Sekuensial Abstrak lebih tinggi daripada siswa yang memiliki Gaya berpikir Sekuensial Konkrit, hal ini disebabkan karakteristik siswa yang memiliki Gaya berpikir Sekuensial Abstrak cenderung berpikirnya logis, rasional, dan intelektual, serta lebih suka bekerja secara mandiri daripada bekerja secara kelompok yang mengakibatkan siswa yang memiliki gaya berpikir Sekuensial Abstrak memperoleh nilai lebih tinggi daripada siswa yang memiliki Gaya berpikir Sekuensial Konkrit pada kelas ekspositori.

Interaksi Antara Strategi Pembelajaran dengan Gaya berpikir terhadap Hasil Belajar Matematika siswa

Temuan penelitian menunjukkan bahwa terdapat interaksi antara strategi Pembelajaran dan Gaya berpikir terhadap hasil belajar Matematika. Siswa yang memiliki Gaya berpikir Sekuensial Konkrit memiliki hasil belajar yang lebih tinggi daripada siswa yang memiliki Gaya berpikir Sekuensial Abstrak yang diajar dengan menggunakan strategi pembelajaran Kooperatif Tipe Jigsaw, demikian pula halnya dengan siswa yang memiliki Gaya berpikir Sekuensial Abstrak memiliki hasil belajar yang lebih tinggi daripada siswa yang memiliki Gaya berpikir Sekuensial Konkrit pada kelas yang diberi strategi pembelajaran ekspositori. Hal ini mengindikasikan adanya interaksi antara penggunaan strategi pembelajaran dengan Gaya berpikir terhadap hasil belajar matematika siswa.
Strategi pembelajaran Kooperatif Tipe Jigsaw merupakan strategi pembelajaran kelompok yang di dalamnya merupakan rangkaian kegiatan belajar yang dilakukan oleh siswa dalam kelompok-kelompok tertentu untuk mencapai tujuan pembelajaran yang telah dirumuskan. Prosedur pembelajaran kooperatif pada prinsipnya terdiri atas empat tahap, yaitu: penjelasan materi, belajar dalam kelompok, penilaian, dan pengakuan tim. Dengan proses pembelajaran tersebut segala aktivitas siswa untuk dapat meningkatkan kemampuannya yang telah dimiliki maupun meningkatkan kemampuan baru, baik kemampuan dalam aspek pengetahuan, sikap, maupun keterampilan. Aktivitas pembelajaran tersebut dilakukan dalam kegiatan kelompok, sehingga antar peserta dapat saling membelajarkan melalui tukar pikiran, pengalaman, maupun gagasan-gagasan untuk mencapai tujuan yang dimaksudkan yaitu untuk memberikan arah perencanaan, pelaksanaan, dan evaluasi. Melalui tujuan yang jelas, setiap anggota kelompok dapat memahami sasaran setiap kegiatan belajar sehingga hal ini akan dapat meningkatkan kemampuan kognitif siswa.

Gaya berpikir Sekuensial Konkrit adalah Gaya berpikir yang cenderung menggunakan otak sebelah kiri lebih dominan dibandingkan dengan otak sebelah kanan. Proses berpikir otak kiri bersifat logis, sekuensial, linier, dan rasional. Otak kiri berpikir secara sekuensial, teratur, logis, dan runtut. Kerja otak kiri adalah keteraturan, kerapian, dan sesuatu yang pasti. Orang yang cenderung teratur dan rapi biasanya selalu mempunyai catatan yang rapi, selalu tepat waktu, terencana, dan tidak suka hal-hal yang bersifat mendadak. Dalam pembelajaran, kegiatan praktik adalah cara belajar yang terbaik bagi orang yang memiliki Gaya berpikir sekuensial konkrit.

Strategi ekspositori merupakan bentuk dari pendekatan berorientasi kepada guru (teacher centered approach) dikatakan demikian sebab dalam strategi ini guru memegang peran yang sangat dominan. Melalui strategi ini guru menyampaikan materi pelajaran yang disampaikan itu dapat dikuasai siswa dengan baik. Fokus utama strategi ini adalah kemampuan akademik (academic achievement) siswa. Metode Pembelajaran dengan kuliah merupakan ciri khas dari strategi pembelajaran ekspositori. 
Strategi pembelajaran ekspositori yang berfokus pada guru dan mengharapkan siswa untuk mendengar dan mencatat materi pelajaran sesuai dengan karakteristik siswa yang memiliki Gaya berpikir Sekuensial Abstrak. Hal ini mengakibatkan hasil belajar matematika siswa yang memiliki Gaya berpikir Sekuensial Konkrit dibelajarkan dengan strategi Kooperatif Tipe Jigsaw lebih tinggi daripada hasil belajar matematika siswa yang memiliki Gaya berpikir Sekuensial Abstrak yang dibelajarkan dengan strategi Kooperatif Tipe Jigsaw dan hasil belajar siswa yang memiliki Gaya berpikir Sekuensial Abstrak yang dibelajarkan dengan strategi pembelajaran ekspositori lebih tinggi daripada siswa daripada siswa yang memiliki Gaya berpikir Sekuensial Konkrit yang dibelajarkan dengan strategi pembelajaran ekspositori.

Dengan demikian melalui gaya berpikir, seorang siswa akan mencoba untuk menjajaki lingkup dan batasan masalah, mencari dan memproses informasi sambil mengembangkan asumsi yang akan mendukung respon jawabannya. Seorang siswa yang cenderung berpikir Sekuensial Konkrit, ia akan cenderung untuk memperhatikan dan mengingat realitas dan mengingat fakta-fakta, informasi, rumus-rumus, dan aturan-aturan khusus dengan mudah. dengan demikian semakin banyak berdiskusi dengan kelompok akan semakin menambah wawasannya. Selain itu ia juga mencoba membandingkan berbagai pandangan untuk mengetahui validitas asumsi dan informasi yang ada.

\section{PENUTUP}

1. Terdapat perbedaan rata-rata hasil belajar matematika antara siswa yang dibelajarkan dengan strategi pembelajaran Kooperatif Tipe Jigsaw dengan siswa yang dibelajarkan dengan strategi pembelajaran Ekspositori. Rata-rata hasil belajar Matematika siswa yang dibelajarkan dengan Strategi Kooperatif Tipe Jigsaw lebih tinggi dari hasil belajar Matematika siswa yang dibelajarkan dengan Strategi Ekspositori. Strategi pembelajaran Kooperatif Tipe Jigsaw lebih efektif diterapkan dalam pembelajaran matematika guna meningkatkan hasil belajar Matematika siswa tanpa memperhatikan adanya perbedaan gaya berpikir.

2. Rata-rata hasil belajar Matematika siswa yang memiliki Gaya berpikir Sekuensial
Konkrit lebih tinggi daripada hasil belajar Matematika siswa yang memiliki Gaya berpikir Sekuensial Abstrak. Rata-rata hasil belajar Matematika siswa dengan Gaya berpikir Sekuensial Konkrit baik secara keseluruhan yang dibelajarkan dengan Strategi pembelajaran Kooperatif Tipe Jigsaw.

3. Terdapat interaksi antara penggunaan Strategi pembelajaran dan Gaya berpikir dalam mempengaruhi hasil belajar Matematika siswa.

\section{DAFTAR PUSTAKA}

Anita Lie. 2007. Cooperative Learning. Jakarta : Grasindo.

Arends 1997. Model-Model Pembelajaran Inovatif berorientasi Konstuktivitis, Jakarta: Prestasi Pustaka Publisher

Azizah Noor. 2007. Keefektifan Penggunaan Model Pembelajaran Kooperatif Teknik Numbered-Heads-Together dengan Pemanfaatan LKS (Lembar Kerja Siswa) Pokok Bahasan Bangun Ruang Sisi Datar (Kubus dan Balok) Siswa. Semarang

Darajat, Z. 2002. Metode Khusus Pengajaran Agama Islam. Jakarta : Bumi Aksara.

Degeng, INS. (1990). Disain Pembelajaran : Teori Ke Terapan. Malang : PPSS IKIP Malang.

Djahiri, A.K. 2004. Dasar - Dasar Metodologi Pengajaran. Bandung : Lab. PPMP UPI Bandung.

Dryden, Gorden dan Jeanette Vos. 2003. The Learning Revoluton. Bandung : Kaifa.

Ellis, C.H. 1978. Fundamental of Human Learning (Memory and Cognition.) Mexico : Wm. C. Brow Company.

Erman Suherman, dkk. (2003). Strategi Pembelajaran Matematika Kontemporer. Bandung: JICA Universitas Pendidikan Indonesia.

Fudyartanto. 2002. Psikologi Pendidikan. Yogyakarta : Global Jakart.

Hamalik, O.2006. Proses Belajar Mengajar. Jakarta : Bumi Aksara.

Hasan, S.H. 1988. Evaluasi Kurikulum. Jakarta : P2LPTK Ditjen Dikti-Depdikbud.

Johnson, D.W., Johnson, R.T. \& JohnsonHolubec, E.J. 2003. Cooperation in the Classroom. Bandung: Alfabeta.

Killen, Roy. 1998. Effective Teaching Strategies. Australia. Social Science Press. 
Lie, A. 2002. Cooperatif Learning. Jakarta: PT Grasindo

Mulyono, A. 1999. Pendidikan bagi Anak berkesulitan Belajar. Jakarta : Rineka Cipta.

Sanjaya, W. 2008. Strategi Pembelajaran Berorientasi Standar Proses Pendidikan. Jakarta : Kencana.

Sanjaya, Wina. (2006). Pembelajaran dalam Implementasi Kurikulum Berbasis Kompetensi. Jakarta :Kencana Prenada Media Group.

Skinner, B.F. ,1969, Contingencies of reinforcement: a theoretical analysis. Appleton-Century-Crofts. p. 283.

Slameto. 2003. Belajar dan Faktor-faktor yang Mempengaruhinya. Jakarta: Rineka Cipta.
Slavin, Robert E. 2004, Cooperative Learning : Teori, Riset dan Praktik, Terjemahan Nurulita. Bandung: Nusa Media

Soedjadi. 2004. Kiat Pendidikan Matematika Di Indonesia. Jakarta : Depdiknas.

Suriasumantri, Jujun S, Filsafat Ilmu: Sebuah Pengantar Populer, Jakarta: Pustaka Sinar Harapan, 1993

Suryabrata, S. 2008. Psikologi Pendidikan. Jakarta : Raja Grafindo Persada.

Uhar Suharsaputra. 2004. Pengembangan dan penggunaan Model Pembelajaran Arias dalam meningkatkan Kualitas Pembelajaran. Makalah.

Van Dallen. 1973. Meaningful Learning. New York: Grune \& Stratton, Inc. 